\title{
Relationships Between Pre-anal fin Length and Total Length of Roughhead Grenadier (Macrourus berglax Lacépède) in the Northwest Atlantic
}

\author{
D. B. Atkinson \\ Department of Fisheries and Oceans, Science Branch \\ Northwest Atlantic Fisheries Centre, P. O. Box 5667 \\ St. John's, Newfoundland, Canada A1C 5X1
}

\begin{abstract}
Tail breakage and regeneration in grenadiers has hindered accurate measurement of their total lengths. In 1980, the Scientific Council of the Northwest Atlantic Fisheries Organization (NAFO) adopted anal fin length (from the tip of the snout to the base of the first anal fin ray) as the standardized length measurement for both roundnose and roughhead grenadier. Linear relationships between total length and anal fin length (more properly called pre-anal fin length) are available for roundnose grenadier, but similar relationships for roughhead grenadier in the Northwest Atlantic have not been derived previously. Analysis of data collected in NAFO Div. 2J and $3 \mathrm{~K}$ in 1978 and 1979 indicate that total length (TL) and pre-anal fin length (AFL) are highly correlated for roughhead grenadier. Unlike in roundnose grenadier, no significant differences were found between the relationships for males and females. The combined relationship is $T L=$ $5.2320+2.3455$ * AFL.
\end{abstract}

\section{Introduction}

In 1980, the Scientific Council of the Northwest Atlantic Fisheries Organization (NAFO) recommended that length measurements of both roundnose grenadier (Coryphaenoides rupestris Gunnerus) and roughhead grenadier (Macrourus berglax Lacépède) be separated by sex and reported as partial lengths, measured from the tip of the snout to the base of the first anal fin ray (called anal fin length by NAFO but more properly termed pre-anal fin length), in half-centimetre intervals (NAFO, 1980). This recommendation arose as a result of studies carried out for roundnose grenadier (Atkinson, 1981) in response to a previously recognized need for an alternative to the total length measurement because of the problem of tail breakage and regeneration in grenadier species (Jensen, MS 1976).

Although commercial fisheries for grenadiers in the Northwest Atlantic are directed primarily toward roundnose grenadier, Savvatimsky (1989) noted that sufficient numbers of roughhead grenadier exist in the Northwest Atlantic to provide an additional resource to trawl fisheries. In addition, a study by Botta and Shaw (1975) indicated that this species stored well on ice, and is very suitable as a food. They pointed out that because of low abundance and density, the species by itself could not support a fishery, but could form an important incidental fishery. Recent increased interest shown by the Canadian fishing industry in development of fisheries and markets for underutilized species, including roughhead grenadier, necessitates closer monitoring of the resource.
Magnússon (MS 1987) reported that the use of total lengths for roughhead grenadier is not as problematic as with roundnose grenadier because tail breakage is less. Nonetheless, use of pre-anal fin lengths was initiated in Iceland in 1978 for both roundnose and roughhead grenadier and also in 1978, the Newfoundland Region of the Canadian Department of Fisheries and Oceans, initiated the same practice in measuring grenadier lengths. Kosswig (MS 1979) utilized preanus lengths (i.e. from the tip of snout to the anus) to overcome inaccuracies in measuring grenadier, and Sahrhage (1986) reported that difficulties associated with total lengths were similar for roughhead and roundnose grenadier.

The purpose of this paper is to provide information concerning the relationship between total length and pre-anal fin length for roughhead grenadier in the Northwest Atlantic.

\section{Materials and Methods}

During otter trawl surveys in Div. 2J and 3K in 1978 and 1979 a total of 486 roughhead grenadier, all deemed by visual examination to have complete tails, were sampled in order to obtain both total length and pre-anal fin length. All measurements were to the nearest half-centimetre. The measured pre-anal fin lengths ranged from 5 to $33.5 \mathrm{~cm}$ corresponding to measured total lengths of 15 to $81.5 \mathrm{~cm}$. This represented the size range usually encountered in the Northwest Atlantic. Of the 486 samples, 289 were sexed ( 119 males and 170 females). 
Linear regression analyses were carried out (Wilkinson (1989)) to derive relationships between total length and pre-anal fin length, first by sex, then for the entire dataset. Before deriving relationships for the entire dataset, analyses of co-variance were done to test the null hypothesis that no differences exist between the slopes or intercepts of the separate relationships for males and females.

\section{Results and Discussion}

Total length and pre-anal fin length were highly correlated for both male and female roughhead grenadier, with correlation coefficients ( $r$ ) of 0.990 and 0.987 respectively. Analysis of co-variance indicated that neither the slopes nor intercepts of the two relationships were significantly different $(P>0.05)$, so a single relationship for both sexes combined was appropriate. Atkinson (1981) indicated that the relationships for male and female roundnose grenadier were signficantly different, but in practical terms the difference was less than the measurement criteria, so it could be ignored. Savvatimsky (MS 1981; MS 1984) also found significant differences between male and female roundnose grenadier.

The relationship with all data combined was also highly significant (Fig. 1), with an r-value of 0.993 (Fratio $=35747.4 ; \mathrm{P}<<0.05)$, is as follows:

$$
\mathrm{TS}=5.2320+2.3455 \text { * } \mathrm{AFL}
$$

where $T L$ is the total length, and AFL is the pre-anal fin length.

Magnússon (MS 1987) has also reported a significant linear relationship between pre-anal fin length and total length for roughhead grenadier taken in Icelandic waters. She documented an average ratio of pre-anal fin length to total length of 0.3835 which was similar to the ratio of 0.3783 estimated from samples used in this study. Assuming that the mean length of fish in the two samples was about the same, this suggests that the present relationship can be applied over a wider area than that sampled.

Kosswig (MS 1979) and Sahrhage (1986) reported a linear relationship between pre-anus length and total length for roughhead grenadier caught off eastern Greenland, and western Barents Sea and Spitzbergen, respectively. However, Atkinson (1981) suggested that because of distortion that could occur in the region of the anus when roundnose grenadier were brought to the surface, and because shore sampling of pre-anus length of gutted fish was not possible, it was preferable to measure pre-anal fin length rather than pre-anus length. Since distortion also occurs with roughhead grenadier, it is preferable to use pre-anal fin length for this species as well.

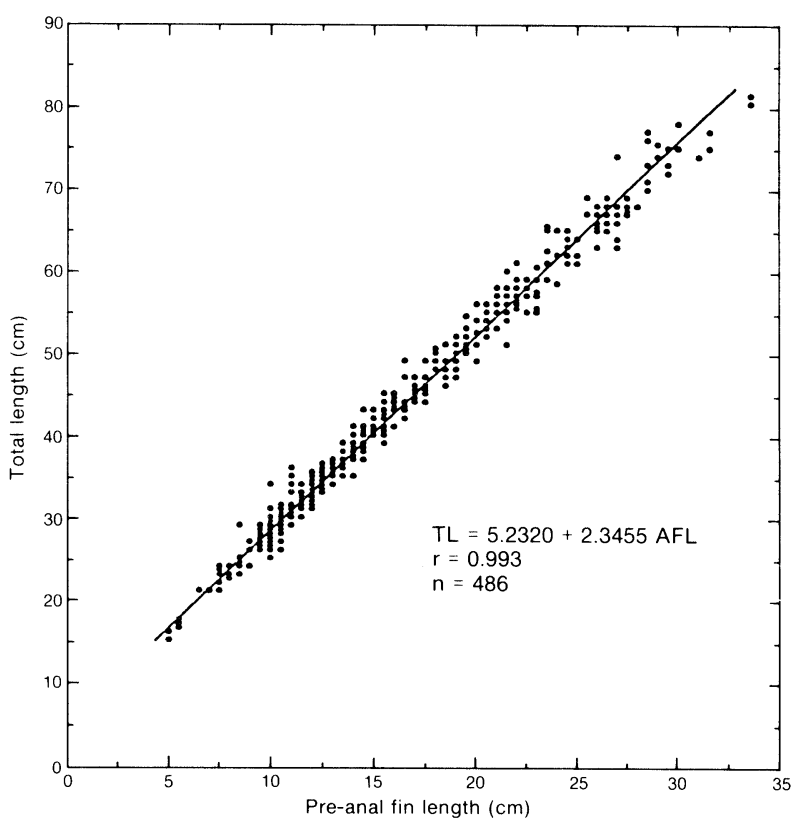

Fig. 1. Data points and derived relationship between total length and pre-anal fin length for roughhead grenadier (sexes combined) from NAFO Div. $2 J$ and $3 K$.

Linear relationships between partial length and total length have been reported by various researchers for roundnose grenadier (e.g. Jensen, MS 1976; Kosswig, MS 1979; Atkinson, 1981; Magnússon, MS 1987). Savvatimsky (MS 1981, MS 1984), however, contended that the pre-anal fin length/total length ratio changed with increasing fish size and as a result, linear regressions should not be used for conversions. Instead, Shibanov and Savvatimsky (MS 1987) derived a key for use in converting from one measurement type to another. Their reasoning was incorrect however, as the linear relationship derived by Atkinson (1981) predicted a change in the pre-anal fin length/total length ratio with increasing fish size. Similarly, for the relationship derived in this paper, the ratio of pre-anal fin length/total length changes with increasing fish size.

\section{References}

ATKINSON, D. B. 1981. Partial length as a replacement for total length in measuring grenadiers. J. Northw. Atl. Fish. Sci., 2: 53-56.

BOTTA, J. R., and D. H. SHAW. 1975. Chemical and sensory analysis of roughhead grenadier (Macrourus berglax) stored in ice. J. Food Sci., 40: 1249-1252.

JENSEN, J. M. MS 1976. Length measurement of roundnose grenadier. ICNAF Res. Doc., No. 93, Serial No. 3913, 2 p.

KOSSWIG, K. MS 1979. A note on the age and growth of the roughhead grenadier (Macrourus berglax Lacépède) at East Greenland (Dohrn Bank) in 1978. ICES C.M. Doc., No. G:59, $4 \mathrm{p}$.

MAGNÚSSON, J. V. MS 1987. Grenadier fish in Iceland waters. NAFO SCR Doc., No. 87, Serial No. N1341, 19 p. 
NAFO. 1980. Report of the Scientific Council, Regular Meeting, June, 1980. NAFO Sci. Coun. Rep., 1979-80: 63-70.

SAHRHAGE, M. 1986. Commercially important grenadiers of the North Atlantic. Mitt. Inst. Seefisch. Hamburg, 37, 81 p. Transl. from German. Can. Transl. Fish. Aquat. Sci., No. $5376,86 \mathrm{p}$

SAVVATIMSKY, P. I. MS 1981. On length measurements of roundnose grenadier (Coryphaenoides rupestris) in the Northwest Atlantic. NAFO SCR Doc., No. 20, Serial No. N296, $11 \mathrm{p}$.

MS 1984. On correlation between total length and pre-anal length of roundnose grenadier (Coryphaenoides rupestris) in the North Atlantic. NAFO SCR Doc., No. 44, Serial No. N829, $14 p$

1989. Investigations of Roughhead grenadier (Macrourus berglax L.) in the Northwest Atlantic, 1967-83. NAFO SCi. Coun. Studies, 13: 59-75.

SHIBANOV, V. N., and P. I. SAVVATIMSKY. MS 1987. Methods of conversion of roundnose grenadier (Coryphaenoides rupestris Gunnerus, Macrouridae) ante-anal distance into zoological length. NAFO SCR Doc., No. 91, Serial No. N1395, $12 \mathrm{p}$.

WILKINSON, Leland. 1989. SYSTAT: The System For Statistics. Evanston, III: SYSTAT Inc. 
